\title{
Reconciliation Processes In Rwanda. The Importance of Tradition and Culture for Transitional Justice
}

\section{Introduction}

In April 2019, 25 years had passed since the Rwandan President, Juvenal Habyarimana, was killed when his aircraft was shot down. This assassination directly ignited ethnic tension in the region and helped spark the mass slaughter in Rwanda. It is estimated that, in the resulting 100 days of genocide, about 500,000 to 1,000,000 people were killed, of which most belonged to the Tutsi ethnic group. In remembrance of those crimes, the President of Rwanda, Paul Kagame, introduced national mourning lasting for 100 days. He also declared that the country had become "a family once again"1, thereby clearly indicating that Rwandans had managed to reconcile. The statement caused a heated debate on the reconciliation processes in Rwanda and their role in peace and security in the region. This paper aims firstly to analyze what reconciliation is - in the context of the countries and regions which have suffered or are suffering situations of conflict or serious human rights violations, which have affected and divided societies in their various facets. Secondly, it contributes to the assessment of reconciliation processes in Rwanda that have been based on tradition and culture: gacaca courts, reconciliation villages and umuganda. Finally, the paper is an attempt to evaluate whether processes based on elements of culture and tradi-

1 Official speech delivered by the President on 8th of April 2019. 
tion may contribute to achieving reconciliation after serious violations of international law.

\section{Reconciliation as an Element of Transitional Justice}

'Reconciliation' is viewed as a key term in transitional justice ${ }^{2}$ and is often presumed to be one of its goals. ${ }^{3}$ It has been used by the UN Secretary General, who clarified that transitional justice denotes a full range of processes and mechanisms associated with a society's attempt to come to terms with a legacy of a large-scale past abuses, in order to ensure accountability, serve justice and achieve reconciliation. ${ }^{4}$ Reconciliation, however, is difficult to define as the concept is quite vague and diverse. It can vary according to culture and can differ due to the nature of the crime. ${ }^{5}$ It can also depend on the political and historical context of the society. Notwithstanding the complexity of the subject, reconciliation can be considered as a process which is aimed at attaining or restoring a relationship between parties that have experienced an oppressive or a destructive situation. ${ }^{6}$ During that process, both parties endeavor to heal trauma and put an end to a period of bad relations. ${ }^{7}$ Reconciliation may begin either with the leaders (top-down process) or at the grass-roots (bottom-up process). ${ }^{8}$ It can be also individual (between

2 See eg.: Justice and Reconciliation - After the Violence, ed. A. Rigby, Boulder 2001; Reconciliation After Violent Conflict, eds D. Bloomfield, T. Barnes and L. Huyse, Stockholm 2003.

3 The Place of Reconciliation in Transitional Justice. Conceptions and Misconceptions, ed. P. Seils, The International Center for Transitional Justice, 2017, p. 3.

4 UN Secretary General, The rule of law and transitional justice in conflict and post conflict societies. Report of the UN Secretary General, 2004, S/2004/615, § 8.

5 Gacaca: Grassroots Justice After Genocide. The Key to Reconciliation in Rwanda?, ed. A. Molenaar, Leiden 2005, p. 31.

6 L. Kriesberg, Changing forms of coexistence, in: Reconciliation, Justice and Coexistence: Theory and Practice, ed. M. Abu-Nimer, New York 2001, p. 48.

7 J. Galtung, After violence, reconciliation and resolution: coping with visible and invisible effects of war and violence, in: Reconciliation, Justice and Coexistence: Theory and Practice, ed. M. Abu-Nimer, New York 2001, p. 3.

8 D. Bar-On, Reconciliation Revisited for More Conceptual and Empirical Clarity, in: Darkness at Moon. War Crimes, Genocide and Memories, ed. J. Bec-Neumann, Sarajevo 2007, 
victim and perpetrator) or collective (between groups or communities). With regard to the first type of the reconciliation, the process should be mutual: both victim and perpetrator must make an effort to overcome the trauma and damages caused by past atrocities. ${ }^{9}$ Collective reconciliation should be understood as a societal process that requires not only the mutual recognition of past suffering, but also a change of attitudes and the desire to reach peace. ${ }^{10}$

As already mentioned, reconciliation (as a goal of the transitional justice) is a broad term that is very hard to define clearly. Researchers indicate, however, a few elements that are essential for achieving the reconciliation, both at the individual and social level. The process requires an apology, forgiveness and desire to rebuild the relationships on the basis of trust. ${ }^{11}$ Reconciliation also involves searching for the truth, justice and healing. ${ }^{12}$ It is important to point out that discovering the truth about past atrocities becomes now the focal point of the reconciliation process, which is very much connected with a development of the right to know the truth (and its growing importance for countries in transition). ${ }^{13}$

p. 81. See also: D. Bar-Tal, G. H. Bennik, The Nature of Reconciliation as an Outcome and a Process, in: From Conflict Resolution to Reconciliation, ed. Y. Bar Simon Tov, Oxford 2004, p. 27.

9 M. Forget, Crime as Interpersonal Conflict: Reconciliation Between Victim and Offender, in: Dilemmas of Reconciliation: Cases and Concepts, eds C.A. Prager, T. Govier, Waterloo 2003, p. 111.

10 See more: Unspeakable Truths: Transitional Justice and the Challenge of Truth Commissions, ed. P. Harney, New York 2011.

$11 \mathrm{~W}$. Lambourne, Justice and reconciliation: post conflict peace building in Cambodia and Rwanda, in: Reconciliation, Justice and Coexistence: Theory and Practice, ed. M. AbuNimer, New York 2001, p. 314.

12 D. Bloomfield, Reconciliation: An Introduction, in: Reconciliation After Violent Conflict: A Handbook, eds D. Bloomfield, T. Barnes, L. Huyse, Stockholm 2003, p. 12.

13 The right to know the truth, although not mentioned expressis verbis in any international treaty, is broadly recognized and enshrined in a number of international instruments, nonbinding resolutions and judicature. See eg. UN Updated Principles for the Protection and Promotion of Human Rights through Action to Combat Impunity, 2005, E/CN.4/2005/102/ Add.1; Basic Principles and Guidelines on the Right to Remedy and Reparations for Victims of Gross Violations of International Human Rights Law and Serious Violations of International Humanitarian Law, adopted by UN General Assembly on 16.12.2005; Resolution on Right to the truth, GA 68/165 (18.12.2013). 
In this regard, reconciliation should aim to acknowledge experiences, uncover unknown facts and events, and enable victims and perpetrators to tell their stories. ${ }^{14}$ The process, therefore, refers to truth-seeking and truth-telling functions. It must be remembered, however, that the truth seems to be a concept that is very hard to pin down. Apart from objective credibility, the "truth" also requires a subjective understanding. This implies an agreement about factual reality, as well as a space for different interpretations. It cannot deepen divisions, but on the contrary, it should lead to healing and coexistence. And this is particularly important in a country such as Rwanda, where the victims and perpetrators were neighbors and still need to live next door to each other.

\section{Gacaca: Grassroot Justice and its Importance for Reconciliation}

After the end of the genocide in Rwanda, there were three types of efforts undertaken in order to deal with the perpetrators: the International Criminal Tribunal for Rwanda (ICTR), the formal domestic justice system, and gacaca courts. Before evaluating and assessing the gacaca courts and their importance for reconciliation process, a few comments must be made with regard to the two other solutions.

The International Criminal Tribunal for Rwanda has undoubtedly had a ground-breaking impact on international criminal justice, e.g. the first-ever conviction by an international court for the crime of genocide. Nevertheless, it should be noted that inside Rwanda the overall assessment of the Tribunal is mixed. The Tribunal is deemed to have been rather inefficient, slow and influenced by policy, and on the other hand, too soft on perpetrators (this negative attitude is maintained mostly by the government of Rwanda). ${ }^{15}$ One of the main criticisms concerned the lack of

14 D. Bloomfield, On Good Terms: Clarifying Reconciliation. Berghof Report No. 14, Berlin 2006, p. 14.

15 Judging Criminal Leaders: the Slow Erosion of Impunity, ed. Y. Beigbeder, Leiden-Boston 2002, p. 221. 
death penalty under the ICTR jurisdiction, while the Rwandan national judicial system used to allow this punishment. ${ }^{16}$ This discrepancy might have led to the situation in which the masterminds of genocide would have received prison terms, whereas other perpetrators (found guilty at the national level) would have been sentenced to death. The Rwandan government also has reservations about the ICTR's temporal jurisdiction and the location of the Tribunal. ${ }^{17}$ These criticism and concerns raise the question of whether the International Criminal Court for Rwanda has contributed in any way to achieving reconciliation inside Rwanda.

The functioning of formal domestic justice in Rwanda and its influence on reconciliation is also a source of some negative assessments. It must be underlined, though, that the national judicial system was almost totally destroyed after the genocide. There were almost no judges or lawyers ${ }^{18}$, and there was virtually no infrastructure, knowledge or experience for dealing with such crimes. ${ }^{19}$ The Rwandan legal system was not set up to accommodate the prosecution of genocide. ${ }^{20}$ Although Rwanda was a party to and ratified the Convention on the Prevention and Punishment of the Crime of Genocide (hereafter also: Convention Against Genocide) $)^{21}$, it failed to enact the enabling legisla-

16 Ibidem, p. 105.

17 T. Longman, The Domestic Impact of the International Criminal Tribunal for Rwanda, in: International War Crimes Trials: Making a Difference?, eds S.R. Ratner, J.L. Bischoff, Austin 2003, p. 35.

18 In December 1994 in Rwanda there were only 12 prosecutors, 59 court clerks and 244 judges/magistrates. D. Bikesha, Administration of Criminal Justice in Aftermath of the Genocide Against the Tutsi: The Case of Gacaca Courts, presentation for Never Again Rwanda, Peace Building Institute, June 2019.

19 I. Martin, Hard Choices After Genocide: Human Rights and Political Failures in Rwanda, in: Hard Choices: Moral Dilemmas in Humanitarian Intervention, ed. J. Moore, Oxford 1998, pp. 152-153.

20 J.B. Mutanga, Domestic Justice Mechanisms: perspectives on referred cases. Paper presented at the International Symposium on the legacy of the ICTR, 2014, <https://unictr. irmct.org/sites/unictr.org/files/publications/compendium-documents/v-domestic-justicemechanisms-mutangana.pdf $>$.

21 Convention on the Prevention and Punishment of the Crime of Genocide, opened for signatures 9 December 1948, A/RES/3/260. In Rwanda the Convention was ratified by the Presidental Decree No 08/75 adopted 12.02.1975, Official Gazetee 1975 [230]. 
tion (the enabling legislation is required by the Convention since the act is not self-executing). ${ }^{22}$ The Rwandan parliament passed the first law punishing genocide only on 1st of September 1996: Organic Law on the Organization of Prosecutions for Offenses constituting the Crime of Genocide or Crimes Against Humanity committed since 1 October 1990 (hereafter also: "Organic Law" 1990). ${ }^{23}$ The purpose of the law was the organization of criminal proceedings against persons who were accused of either the crime of genocide or crimes against humanity, as defined in the Convention Against Genocide. Moreover, the persons accused of such offences were classified in four categories, with different types of penalties (Chapter II). ${ }^{24}$ The law also established a special confession and guilty plea procedure (Chapter III), under which perpetrators could get reduced sentence in exchange for their confessions. Confession, however, had to include a detailed description of all offences (including the names of victims), information about accomplices or conspirators, an apology, and an offer to plead guilty to the offences. Despite all the efforts made to adopt the Rwandan legal system to the post genocide situation, a few issues still remained unresolved. The main problem was the slow speed of the trials due to the huge number of genocide suspects. The Rwandan government estimated that it would take about

22 W.A. Schabas, Genocide in International Law, Cambridge 2009, p. 405.

23 Organic Law No. 08/1996 of 1996 on the Organization of Prosecutions for Offenses constituting the Crime of Genocide or Crimes Against Humanity committed since 1 October 1990, adopted 1.09.1996.

24 Category 1 includes: a) planners, organizers, instigators, supervisors and leaders of the crime of genocide or of a crime against humanity; b) persons who acted in positions of authority at the national, prefectoral, communal, sector or cell level, or in a political party, the army, religious organizations or in a militia and who perpetrated or fostered such crimes; c) notorious murderers who by virtue of the zeal or excessive malice with which they committed atrocities, distinguished themselves in their areas of residence or where they passed; d) persons who committed acts of sexual torture. Category 2 includes persons whose criminal acts or whose acts of criminal participation place them among perpetrators, conspirators or accomplices of intentional homicide or of serious assault against the person causing death. Category 3 includes persons whose criminal acts or whose acts of criminal participation make them guilty of other serious assaults against the person. Category 4 includes persons who committed offenses against property. 
200 years, at that speed, to prosecute all the suspects. ${ }^{25}$ Another serious issue was the fact that prisons in Rwanda were (and still remain) heavily congested. Moreover, imprisonment of the great number of perpetrators caused (and still causes) a tremendous burden economically, socially and psychologically. ${ }^{26}$ These issues call into question the contribution of formal domestic justice system to reconciliation in Rwanda.

Given the problems with the ICTR and the formal national courts, the third, alternative, solution was adopted in Rwanda: gacaca courts ("gacaca” in Kinyarwandan, a local language, means "the grass lawn”). By establishing the institution, recourse was made to traditional mechanisms used in Rwanda. The proposal for the gacaca courts was made by presidential commission in June 1999, but legislation enacting the courts was passed in January 2001. ${ }^{27}$ The gacaca were only implemented, however, in $2006^{28}$ and were officially ended in 2012. Traditionally, the courts were held outside - in markets, yards or other public places in a community. It involved the confessions of perpetrators, expressions of remorse, asking for forgiveness and reparation. ${ }^{29}$ Rwandans had been familiar with the gacaca for many years and, therefore, it was easier for them to participate in the whole process of accounting for genocide. ${ }^{30}$

25 E. Daly, Between Punitive and Reconstructive Justice: The Gacaca Courts in Rwanda, "New York University Journal of International Law and Politics" 2002, no. 34, p. 369.

26 M. Sosnov, The Adjudication of Genocide: Gacaca and the Road to Reconciliation in Rwanda, "Denver Journal of International Law and Policy" 2008, no. 36(2), p. 132.

27 "Organic Law" 2000, no. 40, Setting Up Gacaca Jurisdictions and Organizing Prosecutions For Offences Constituting the Crime of Genocide or Crimes Against Humanity Committed Between October 1, 1990 and December 31, 1994, adopted 26.01.2001, The law was modified few times, including the revision in 2004: “Organic Law” 2004, no. 16, Establishing the Organization, Competence and Functioning of Gacaca Courts Charged With Prosecuting and Trying the Perpetrators of the Crime of Genocide and Other Crimes Against Humanity, Committed Between October 1, 1990 and December 31, 1994, adopted 19.06.2004.

28 There was a pilot program started in July 2002 but it was applied only in some sector levels of a geographic administration. Since March 2005, in the whole country, information has been collected, and all suspects have been classified within four categories. After July 2006, actual proceedings started.

29 Genocide, Justice and Rwanda's Gacaca Courts, eds H.N. Brehm, Ch. Uggen, J. Gasanabo, "Journal of Contemporary Criminal Justice" 2014, no. 36(3), p. 336.

30 M. Sosnov, The Adjudication of Genocide..., p. 135. 
The gacaca courts, although they were meant to be an alternative to the national judicial system, were still deeply rooted in culture and tradition. The linkages were visible in the structure of the institution, including the selection of judges. As there were just a few professional judges left after the genocide, it was decided that members of community would serve as gacaca judges. It must be emphasized that no legal training was required; the judges were selected only on the basis of their commitment to justice and truth. ${ }^{31}$ References to the culture and tradition were also made while setting the objectives for the gacaca. The courts were designed to achieve five main goals:

- to discover the truth about what happened,

- to speed up the genocide trials,

- to eradicate the culture of impunity,

- to reconcile the Rwandans and reinforce their unity,

- to prove that Rwandan society has the capacity to settle its own problems through a system of justice based on Rwandan customs. $^{32}$

Taking into account these objectives, divergent views regarding the purpose of the gacaca may appear. A point of contention is whether the institution had mainly a retributive purpose or whether it had rather restorative nature. The gacaca courts, indeed, aimed to hold the perpetrators accountable ${ }^{33}$ and punish them, ${ }^{34}$ as is confirmed by numbers: 1,958,634 cases were tried

31 Additional requirements: the judges had to be 21 year old or older, have no criminal record and were not allowed to have had a political background. More about this see H.N. Brehm, op. cit.

32 The objectives set by National Service of Gacaca Jurisdiction, The Objectives of the Gacaca Courts.

33 Gacaca courts were allowed to adopt the same four categories of genocide suspects that were implemented by traditional courts. See “Organic Law” 2000, no. 40 [§3 and §51]. In 2004 the number of suspects categories were reduced from four to three. See "Organic Law" 2004, no. 16 [§51].

34 For the perpetrators that were classified to category 1 , the death penalty or life imprisonment could have been applied (“Organic Law” 2000, no. 40 [§68] and “Organic Law” 2004, no. 16 [§72]. The death penalty was abolished in 2007 and after this life imprisonment was the most severe penalty. 
in total, 1,681,648 of which resulted in convictions and 277,066 in acquittals. Just to compare, in the period of 1996-2008 national courts completed only 10,248 cases. ${ }^{35}$ Yet, on the other hand, the victims and the local community were also strongly taken into account by the gacaca courts. Restoring the peace, truth, healing and forgiveness were among the main goals of the institution, which has great promise for achieving reconciliation. ${ }^{36}$

Despite the earlier hope of the gacaca's contribution for achieving reconciliation in Rwanda, the role of the institution still remains unclear. The courts indeed had a great potential to provide a more complete picture of atrocities and to enable both parties to reconcile, but the question arises as to whether the potential was fully realized. The Rwandan government has argued that people accused before the gacaca demonstrated their willingness to confess and for the truth about their crimes to be discovered. ${ }^{37}$ According to data provided by the National Service of Gacaca Jurisdiction, there were 225,012 confessions made before the gacaca, which one can consider as a significant achievement. In this regard, an important issue should be elaborated - a special plea bargaining system laid down by art. 72 et seq. of the "Organic Law" 2004, no. 16. The system allowed perpetrators to have their penalties significantly reduced. For instance, for defendants in the second category, who confessed during gacaca, the time in prison could be reduced by $50 \%$ (art. 73). The plea bargaining system required, though, some criteria to be fulfilled. The perpetrator had to give a detailed description of their crimes, including information of where and when the offences had been committed, information about the victims and about the place where the death occurred or where the body was left. Furthermore, the defendant had to reveal the co-authors and accomplices, and to apologize. Apologies had to be made publicly, in front of the victims

35 The dates provided by National Service of Gacaca Jurisdiction.

36 See more: P. Clack, The Gacaca courts, post-genocide justice and reconciliation in Rwanda: Justice without lawyers, New York 2010.

37 See National Service of Gacaca Jurisdiction, The Objectives of the Gacaca Courts. More about this: M. Sosnov, The Adjudication of Genocide... 
if they were still alive (art. 54). There were also other benefits received by perpetrators when they plead guilty (also for perpetrators that had already been in prisons). They were offered a less strict prison regime, they could participate in labor projects, and they were allowed to have more meetings with friends and relatives. ${ }^{38}$

The plea bargaining system did indeed contribute to perpetrators making confessions, but it is questionable whether it greatly helped in uncovering the truth and achieving reconciliation. The confessions did not provide full disclosure of people's participation in genocide. ${ }^{39}$ People tended to confess to only one or two crimes and to blame others for more serious atrocities. ${ }^{40}$ This, in turn, not only did not allow Rwandans to reconcile, but it rather encouraged uncertainty and suspicion between people. It referred, in particular, to crimes which were considered as a source of shame and contempt. In the case of rape, public confessions were very rare, and neither did victims want to testify. ${ }^{41}$ This was mostly caused by the fact that the crime of rape is of an intimate nature, as well as the fact that sexuality and carnality are very much influenced by Rwandan tradition, culture and beliefs. Rape victims very often had to face ostracism from the community, and even from their families. ${ }^{42}$ It was also believed that discussing sexual violence would cause ethnic tensions and stop the process of reconciliation. ${ }^{43}$

The analysis of the gacaca courts would be incomplete without mentioning some legal issues caused by the institution. It is not the main goal of the paper, nevertheless brief mention needs to be made of the fact that the gacaca violated several fair trial standards established by international and national law. These include the right to defence,

38 A. Molenaar, op. cit, pp. 54-55.

39 Ibidem, p. 72.

40 E. Zorbas, Reconciliation in Post-Genocide Rwanda, “African Journal of Legal Studies” 2004, no. 29, p. 36.

41 S.L. Well, Gender, Sexual Violence and Prospects for Justice at the Gacaca Courts in Rwanda, "Southern California Review of Law and Women's Studies” 2005, no. 14, p. 187. 42 Ibidem.

43 Ibidem. 
judicial independence, and the presumption of innocence. The gacaca courts were, without doubt, the solution taken to deal with the specific situation in Rwanda (e.g. a huge number of perpetrators, no judges nor legal structures in the country, no trust among people) and they were empowered by Rwandan tradition and culture. The institution enabled Rwandans to participate in the whole process of accounting for genocide and to make public confessions. However, it is questionable whether it contributed to achieving reconciliation in Rwanda.

\section{Umuganda and Reconciliation Villages: Tradition-Based Practices in Reconciliation Policy}

Reconciliation, as already mentioned, is a complex process that should also be carried out between groups and communities. The process cannot be finished until the society has peace and security, until coexistence between survivors and perpetrators is reached. In post-conflict societies, coexistence should be understood as going beyond just living together. It should include mutual tolerance, forgiveness and even respect. ${ }^{44}$ In order to reach such a level of coexistence, it is first required to free people from isolation, fear and hate. Great efforts should be directed towards initiating special policy and dialogue between victims and defendants. ${ }^{45}$ Those initiatives have to be realistic and not cause additional trauma, and preferably they should be based on local traditions and culture.

The issue of peaceful coexistence remains very current problem in Rwanda, as many perpetrators have been released from prisons. An issue arose with regard to their inclusion and integration with society. To address this, a few initiatives were undertaken by Rwandan authorities and institutions, one of which is a reconciliation village. The project is carried out by the non-governmental organization Prison Fellowship Rwanda, with the support of the National Unity and Reconciliation Com-

44 L. Kriesberg, Changing forms of coexistence, p. 48.

45 B. Bloomfield, op. cit., p. 18. 
mission. ${ }^{46}$ The aim of the reconciliation villages is mainly to provide victims and perpetrators with a chance to live together and to integrate. The NGO supplies survivors and defendants with materials that they use to build houses in which they live side by side and work together to maintain. Since 2003, 8 reconciliation villages have been established in Rwanda, about 820 houses have been constructed, accommodating more than 4,000 Rwandans. ${ }^{47}$ The initiative, although supported by local authorities and Rwandans themselves, arouses controversy. The controversy is mostly centred on trauma and the continued victimization of survivors who have to live next door to their perpetrators.

The project of reconciliation villages is supported by other homegrown initiatives based in Rwandan culture and history, such as umuganda. The concept of umuganda takes root from the Rwandan culture of self-help and cooperation, and in Kinyarwanda it can be translated as 'coming together in common purpose to achieve an outcome'. Traditionally, Rwandans would call upon their family, friends and neighbors to help them complete a difficult task. Nowadays, umuganda became mandatory and was institutionalized with the laws passed in $2007^{48}$ and 2009. ${ }^{49}$ On the last Saturday of each month, all citizens (able persons aged 16 to 65) work together (on activities such as tree planting, building houses, cleaning streets) in order to foster growth and reconcile.

The concept of reconciliation villages, as well as umuganda, is justified by the Rwandan culture and tradition. These initiatives seem to be well-known and understood by Rwandans, which may lead to their stronger involvement in the reconciliation. Nevertheless, umuganda, like reconciliation villages, still raises some doubts over its real contribution to the process. With reference to reconciliation villages, it should be con-

46 National Unity and Reconciliation Commission (hereafter: NURC) was created in March 1999 by a parliamentary law to promote unity and reconciliation among Rwandans ("Law" 1999, no. 3). The NURC became a permanent body in 2002.

47 Data provided by Prison Fellowship Rwanda: <https://pfrwanda.com>.

48 “Organic Law” 2007, no. 53, Governing Community Works, adopted on 17.11.2007.

49 Prime Ministerial Order No. 58/03, adopted on 24.08.2009. 
sidered whether victims and perpetrators living next door to each other does not cause more trauma and further victimization. In my opinion, it does, or at least it may lead to such a situation. Regarding umuganda, the activity may create further fear and mistrust, as forced social bonds are well-known from earlier times. Furthermore, during umuganda people have to implement governmental instructions and plans, as they do in reconciliation villages. Therefore, some Rwandans participate in the initiatives out of fear, in order to avoid being seen as antigovernment.

\section{Conclusions}

In the transitional period that follows a time of serious violations of international law, a few questions arise with regard to the social attitude towards the past. This includes not only the official perception of the history, but also the relations between survivors and perpetrators. The State and the whole community must decide what is the most essential for them in order to close the period of suffering and to reconcile. It must be clarified whether the offenders will be severely punished or whether it is more valuable for the society to refrain from punishment in order not to perpetuate social division and hate. In a transitional period it is crucial to perform processes that enable the community to learn the truth about past atrocities, to forgive and to coexist peacefully. Only by reaching these goals will survivors and perpetrators, and consequently the whole society, be able to achieve reconciliation.

The issues mentioned above are still highly topical in Rwanda, and their pursuit remains a key priority for Rwandan authorities and society. A few initiatives have been undertaken in order to help victims and perpetrators overcome the results of past atrocities and to reconcile. The initiatives were both of a repressive and retributive nature. They were, to a large extent, based on elements of Rwandan culture and tradition that were well known in the whole of society. The aim was to increase the public contribution in the reconciliation process. However, 
the evaluation of the results of these initiatives still remains uncertain and may lead to doubts. Using traditional methods made the whole process more community-centered, open and transparent. It permitted victims and defendants to participate actively in the initiatives and, consequently, it made their reconciliation more likely and more successful. The gacaca courts allowed perpetrators to plead guilty and apologize, and on the other hand, it enabled victims to offer mercy and forgiveness. There was a similar situation with umuganda and reconciliation villages, which provided an opportunity to work together in order to reach a common purpose. The initiatives covered the basic needs and expectations of the victims and perpetrators, and gave them the sense of influence over their future. The institution was affordable and open for everyone seeking justice, irrespective of social status or past experience. This, in turn, can significantly accelerate the reconciliation process in the whole country.

Despite all the advantages of the traditional mechanisms adapted in Rwanda in order to bring about reconciliation, a few weaknesses have to be pointed out. It is questionable whether these initiatives (living next door to victims and perpetrators and working hand in hand, in particular) do not cause more trauma and are not a source of further victimization. It is mandatory to participate in these initiatives, as well as to contribute to the mercy and forgiveness process. This in turn entails that victims may not have the space necessary for grief and the slow process of healing. It may also lead to the reconciliation being achieved only out of fear, as it might have been foisted upon Rwandans.

To sum up, traditional mechanisms are very useful in reconciliation and peace-building processes. They have great potential to enable victims and perpetrators to reintegrate and heal. They can be easily associated with something familiar and understandable and, therefore, can increase public participation. It must be remembered, however, that these mechanisms cannot only be imposed from the top down, because this may have negative outcomes and consequently hamper the reconciliation process. 
Reconciliation Processes In Rwanda. The Importance of Tradition... | 95

\section{References}

Bar-On D., Reconciliation Revisited for More Conceptual and Empirical Clarity, in: Darkness at Moon. War Crimes, Genocide and Memories, ed. J. Bec-Neumann, Sarajevo 2007.

Bar-Tal D., Bennik G.H., The Nature of Reconciliation as an Outcome and a Process, in: From Conflict Resolution to Reconciliation, ed. Y. Bar Simon Tov, Oxford 2004.

Basic Principles and Guidelines on the Right to Remedy and Reparations for Victims of Gross Violations of International Human Rights Law and Serious Violations of International Humanitarian Law, adopted by UN General Assembly on 16.12.2005.

Bikesha D., Administration of Criminal Justice in Aftermath of the Genocide Against the Tutsi: The Case of Gacaca Courts, presentation for Never Again Rwanda, Peace Building Institute, June 2019.

Bloomfield D., On Good Terms: Clarifying Reconciliation. Berghof Report No. 14, Berlin 2006.

Bloomfield D., Reconciliation: An Introduction, in: Reconciliation After Violent Conflict: A Handbook, eds D. Bloomfield, T. Barnes, L. Huyse, Stockholm 2003.

Clack P., The Gacaca courts, post-genocide justice and reconciliation in Rwanda: Justice without lawyers, New York 2010.

Convention on the Prevention and Punishment of the Crime of Genocide, opened for signatures 9 December 1948, A/RES/3/260.

Daly E., Between Punitive and Reconstructive Justice: The Gacaca Courts in Rwanda, "New York University Journal of International Law and Politics” 2002, no. 34.

Forget M., Crime as Interpersonal Conflict: Reconciliation Between Victim and Offender, in: Dilemmas of Reconciliation: Cases and Concepts, eds C.A. Prager, T. Govier, Waterloo 2003.

Gacaca: Grassroots Justice After Genocide. The Key to Reconciliation in Rwanda?, ed. A. Molenaar, Leiden 2005. 
Galtung J., After violence, reconciliation and resolution: coping with visible and invisible effects of war and violence, in: Reconciliation, Justice and Coexistence: Theory and Practice, ed. M. Abu-Nimer, New York 2001. Genocide, Justice and Rwanda’s Gacaca Courts, eds H.N. Brehm, Ch. Uggen, J. Gasanabo, “Journal of Contemporary Criminal Justice” 2014, no. 36(3). Judging Criminal Leaders: the Slow Erosion of Impunity, ed. Y. Beigbeder, Leiden-Boston 2002.

Justice and Reconciliation - After the Violence, ed. A. Rigby, Boulder 2001. Kriesberg L., Changing forms of coexistence, in: Reconciliation, Justice and Coexistence: Theory and Practice, ed. M. Abu-Nimer, New York 2001.

Lambourne W., Justice and reconciliation: post conflict peace building in Cambodia and Rwanda, in: Reconciliation, Justice and Coexistence: Theory and Practice, ed. M. Abu-Nimer, New York 2001.

Longman T., The Domestic Impact of the International Criminal Tribunal for Rwanda, in: International War Crimes Trials: Making a Difference?, eds S.R. Ratner, J.L. Bischoff, Austin 2003.

Martin I., Hard Choices After Genocide: Human Rights and Political Failures in Rwanda, in: Hard Choices: Moral Dilemmas in Humanitarian Intervention, ed. J. Moore, Oxford 1998.

Mutanga J.B., Domestic Justice Mechanisms: perspectives on referred cases. Paper presented at the International Symposium on the legacy of the ICTR, 2014, <https://unictr.irmct.org/sites/unictr.org/files/publications/compendium-documents/v-domestic-justice-mechanisms-mutangana.pdf $>$.

Organic Law No. 08/1996 of 1996 on the Organization of Prosecutions for Offenses constituting the Crime of Genocide or Crimes Against Humanity committed since 1 October 1990, adopted 1.09.1996, <https://www.refworld.org/docid/3ae6b4f64.html>.

“Organic Law" 2004, no. 16, Establishing the Organization, Competence and Functioning of Gacaca Courts Charged With Prosecuting and Trying the Perpetrators of the Crime of Genocide and Other Crimes Against Humanity, Committed Between October 1, 1990 and December 31, 1994, adopted 19.06.2004. 
“Organic Law” 2004, no. 16.

“Organic Law” 2000, no. 40, Setting Up Gacaca Jurisdictions and Organizing Prosecutions For Offences Constituting the Crime of Genocide or Crimes Against Humanity Committed Between October 1, 1990 and December 31, 1994, adopted 26.01.2001

“Organic Law” 2007, no. 53, Governing Community Works, adopted on 17.11.2007.

Presidental Decree No 08/75 adopted 12.02.1975, Official Gazetee 1975 [230].

Prime Ministerial Order No. 58/03, adopted on 24.08.2009.

Reconciliation After Violent Conflict, eds D. Bloomfield, T. Barnes and L. Huyse, Stockholm 2003.

Resolution on Right to the truth, GA 68/165.

Schabas W.A., Genocide in International Law, Cambridge 2009.

Sosnov M., The Adjudication of Genocide: Gacaca and the Road to Reconciliation in Rwanda, "Denver Journal of International Law and Policy” 2008, no. 36(2).

The Place of Reconciliation in Transitional Justice. Conceptions and Misconceptions, ed. P. Seils, The International Center for Transitional Justice, 2017.

UN Secretary General, The rule of law and transitional justice in conflict and post conflict societies. Report of the UN Secretary General, 2004, S/2004/615, § 8.

UN Updated Principles for the Protection and Promotion of Human Rights through Action to Combat Impunity, 2005, E/CN.4/2005/102/Add.1. Unspeakable Truths: Transitional Justice and the Challenge of Truth Commissions, ed. P. Harney, New York 2011.

Well S.L., Gender, Sexual Violence and Prospects for Justice at the Gacaca Courts in Rwanda, "Southern California Review of Law and Women’s Studies” 2005, no. 14.

Zorbas E., Reconciliation in Post-Genocide Rwanda, “African Journal of Legal Studies” 2004, no. 29. 


\section{SUMMARY}

\section{Reconciliation Processes in Rwanda. The Importance of Tradition and Culture for Transitional Justice}

In 1994, Rwanda suffered one of the worst genocides in history. It is estimated that up to $1,000,000$ people were killed in the 100 days of mass slaughter. In 2019, 25 years after the atrocities, Rwanda and Rwandans are still involved in transitional processes aimed at rebuilding the country, handling the past crimes and, ultimately, achieving reconciliation. In the first part of the paper the significance of the reconciliation is elaborated. Reconciliation is often presumed to be one of the main goals for transitional justice and an essential element for rebuilding peace and security in post-conflict countries. It is also the process during which victims and perpetrators attain or restore a relationship and heal their trauma. In the second part of the paper, the importance of local tradition and cultures for transitional justice is discussed. The attention is paid to gacaca courts, reconciliation villages and umuganda, and to their roles in achieving reconciliation in Rwanda.

Keywords: Rwanda, reconciliation, gacaca courts, umuganda, reconciliation villages

Małgorzata Myl, University of Silesia in Katowice, Faculty of Law and Administration, ul. Bankowa 11B, 40-007 Katowice, e-mail: malgorzata.myl@us.edu.pl.

DOI 10.14746/ppuam.2020.11.05 